\title{
NOTES
}

\section{SEC REGULATION OF AMERICAN DEPOSITARY RECEIPTS: DISCLOSURE, LTD.}

INVESTMENT abroad has taken three forms: government spending, direct investment in foreign industry, and portfolio investment in foreign securities. Of the three, purchase of foreign securities has been the smallest in dollar volume. ${ }^{1}$ But revived interest in trading foreign securities and subsequent revision of SEC regulatory controls suggest re-examination of the mechanics and regulation of portfolio investment in foreign industry.

\section{Mechanics of Trading Foreign Shares}

Trading in foreign shares subjects the trader to risks and inconveniences beyond those involved in trading domestic issues. Aside from the obvious time and language barriers separating domestic investors and foreign markets, foreign stock certificates appear in several unfamiliar forms. Use of registered shares entails costly shipping charges and delays occasioned by the absence of transfer agents in this country $;^{2}$ use of bearer shares entails a larger risk of loss and requires attention to foreign publications for notice of disbursements. ${ }^{3}$ Use of either gives rise to problems in foreign exchange, including not only

1. In the postwar period from mid-1945 through $1952, \$ 46.5$ billion of American capital was spent abroad. Of the $\$ 6.2$ billion annual average, $\$ 5.42$ billion represented government expenditure for reconstruction and development, $\$ 0.64$ billion was invested directly by private sources and $\$ 0.14$ billion went into portfolio investments. BucHanaN \& ElLIs, Approaches to Econoairc Developarent 343-44 (1955). Of the private capital, half ( $\$ 0.43$ billion) in a typical year (1952) went to Canada. THORP, TrADE, AId, OR What? 185 (1954). But see Business Week, March 31, 1956, p. 62.

For further discussion of foreign investments, see, generally, Mrkesel, United States Economic Policy and International Relations 216-33 (1952); Woodrow Wilson Foundation \& The national Planning Association, The Political Economy of Americhn Foreign Policy 328-39 (1955).

2. Few foreign corporations have transfer agents in this country. English corporations are prohibited from having transfer agents outside the Commonwealth. Transfer of an English registered share requires a separate transfer deed. See 24 Halsbury's Statutes of ENGLAND 471 (2d ed. 1950). Transactions in English shares are delayed further by the London custom of settling accounts on fortnightly "settlement days." MunN, ENcyctopedia of Banking and Finance 729 (4th ed. 1937).

3. European investors have long preferred bearer to registered shares because of their negotiability and anonymity. It was only to comply with restrictions aimed at blocking capital flight that English corporations replaced their bearer shares with registered. Collecting dividends on bearer shares necessitates following the financial publications which advise when and where the coupons attached to the shares may be presented for payment. Guaranty Trust Co. of New York, Memorandum on AmreriCAN Defository Receipts 3 (rev'd Sept. 15, 1947) (hereinafter cited as Guarantry Mearo). 
the usual risks of freely fluctuating rates but also the danger of foreign regulations fixing exchange rates and restricting capital exports." Combined with the reluctance of foreign companies to issue shares in America, the mechanical difficulties of trading foreign shares ordinarily results in a narrow New York market with characteristically wide spreads.

To eliminate most of the mechanical problems, the American financial community in the twenties developed the vehicle of substitute certificates. ${ }^{5}$ The substitute certificate represented an agreement between a depositor, depositary and shareholder; the foreign company whose shares were to be traded was not a party to the agreement. ${ }^{6}$ The depositor was generally an American investment house anxious to facilitate local placement of a block of shares which it held in the foreign company. ${ }^{7}$ The depositary was a domestic bank which undertook to hold the actual foreign shares for the depositor, and to issue depositary receipts against them. ${ }^{8}$ The receipts, which resembled domestic

4. Several countries in fact accord foreign capital preferential rates on import, and specifically provide for repayment of capital and income. IntERnational Monetary Fund, Sixtr Ann. Rep. on Exchange Restrictions 59-65 (Brazil), 301-10 (United Kingdom) (1955). But the irregular revision of foreign exchange regulations-and "revision" of foreign governments themselves-make for uncertainty. Today the currency of forty-five of the fifty-six member nations of the International Monetary Fund is still considered sufficiently unstable that "transitional" governmental regulation is justified. Id. at $21,25,325$. The eleven "free exchange" nations are all in the western hemisphere, tied to dollar prosperity; these nations in the past have not been the most important in terms of American portfolio investment.

For discussion of the impact of foreign exchange control on private investment, see Mikeseli, Foreign Exchange in the Postwar World 449-56, 472-73 (1954).

5. Although substitute certificates for foreign shares were first introduced in 1916, they were seldom used until promoted by the exchanges in 1927. Guaranty Memo 1, 4.

6. At first the agreement for deposit was a separate document pursuant to which substitute certificates were issued. See, e.g., Agreement between Kuhn, Loeb \& Co., The Equitable Trust Co. of New York and "all present and future holders of certificates issued and to be issued hereunder," p. 1 (Sept. 10, 1918) (Royal Dutch), on file in Yale Law Library. Subsequently, the deposit agreement became part of the substitute certificate itself. See note 13 infra.

Little documentary material is available on the use of substitute certificates. Much of the descriptive information following is based upon a series of interviews with staff members of the SEC and officials of prominent New York banks dealing in the certificates.

7. The depositor or depositors maintained the right to exercise key managerial control of the deposit. Official. Report of Proceedings Before The Securities and Exchange Commission, Conference on American Depositary Receipts 56 (June 20, 1955) (hereinafter cited as ADR REPORT). See also, e.g., Agreement between Kuhn, Loeb \& Co. and The Equitable Trust Co. of New York, p. 1 (Aug. 28, 1919) (Shell Transport Co.), on file in Yale Law Library. In this agreement the depositor retained control of voting rights, $i d$. at 7 , disbursements to shareholders, $i d$. at 5-6, and removal of the depositary, id. at 15 . Furthermore, in order to give the depositor a stable market in which to sell the certificates, the deposit agreement allowed the initial depositor a specified period during which it alone could deposit the foreign shares. Id. at 4.

8. See, e.g., Royal Dutch and Shell Transport agreements, supra notes 6, 7. At first the foreign shares were actually deposited in New York, but this created a shipping prob- 
stock certificates, were then distributed by the depositor to its customers. ${ }^{9}$ The investor thus became a shareholder in effect, although his name did not appear on the books of the foreign company, by virtue of the deposit agreement which gave him a right to obtain the underlying foreign shares. He received dividends from the depositary, already converted by it into domestic currency, and was able to sell the depositary receipt on the American market. ${ }^{10}$ Arbitrage liept the American price in line with the price for the actual share abroad.

The substitute certificate of today, known as an American Depositary Receipt (ADR), ${ }^{11}$ represents a major variation of the same principle of local issue against deposit abroad. Today, there is no single depositor. Instead, the depositary bank has assumed the initiative; it announces that it stands ready to issue ADR's in New York against deposit of designated securities abroad. ${ }^{12}$ The depositors, generally domestic dealers or private shareholders owning shares in the foreign company, then undertake to have securities lodged with

lem, particularly troublesome in the event of a stock split. Thus the underlying shares came to be held abroad by the American bank's branch or agent.

Other functions of the depositary were to keep transfer books available to the public, distribute dividends and allow the shareholders to vote through it (or to vote itself if the privilege were so reserved).

9. In addition to the familiar format, a number of foreign shares were often combined to equal one American share so that the price to the American investor would be more in line with the average American share than would be the case where the typically low priced foreign share were represented one for one. See Irving Trust Co. financial announcement, May 25, 1955, on file in Yale Law Library.

10. See, e.g., Ford Motor Co., Ltd., depositary receipt, on file in Yale Law Library.

The depositary was authorized to distribute all disbursements as cash. Thus the shareholder might lose the opportunity to exercise subscription rights made available by the company. Security regulations treated such disbursements as new issues. 48 Stat. 74 (1933), as amended, 15 U.S.C. $\$ 77 \mathrm{~b}(3)$ (1952). And the SEC has ruled that the depositary or American broker receiving such rights for a certificate holder may only notify the holder of their receipt, and then sell the rights abroad as broker for the holder or buy the rights from the holder and sell them abroad as principal. There could be no trading of rights in this country without registration. SEC, Securities Act of 1.933, Release No. 3266, Nov. 25, 1947.

11. The financial community speaks of all substitute certificates as "ADR's," or, occasionally, as "CD's" (certificates of deposit). The technical distinction between American Share Certificates (separate certificate and deposit agreement, traded on the New York Stock Exchange), American Participation Certificates (for foreign bonds) and American Depositary Receipts (integrated certificate and deposit agreement, traded on the American Stock Exchange) is of little significance.

12. Sec, e.g., Irving Trust Co. financial announcement, N.Y. Times, Nov. 28, 1955, p. 41, cols. 7-8; financial release of Guaranty Trust Co. of New York, on file in Yale Law Library; lodgement agreement of Irving Trust Co. with National Provincial Bank, Ltd., on file in Yale Law Library.

In selecting foreign companies for whose shares ADR's will be issued, the depositary banks have considered as the most important factor the interest there might be in America for such an investment. While the depositary naturally investigates the character of the company, nothing in the mechanics of the substitute certificates can be construed as a recommendation of the company to the investor. 
the depositary's foreign agent, in return for ADR's to be issued by the bank. ${ }^{13}$ The foreign company still is not involved, although naturally the bank which issues the ADR's has received its permission to do so.

\section{Federal Regulation of ADR's}

The federal securities regulations introduced in the thirties extended to the market for ADR's. They were considered to be "securities" under the Securities Act of $1933^{14}$ and the Securities Exchange Act of $1934 .^{15}$ Under SEC regulations they were subject to registration and listing requirements substantially identical with those established for domestic shares. ${ }^{10}$ Both registration and listing forms required detailed information about the depositor, the depositary and the terms of deposit. The depositor was considered to be the registrant and was required to sign as issuer of the ADR. ${ }^{17}$ In addition, if the foreign share represented by the ADR would have been subject to registration if issued directly to the public, the foreign company was required both to reveal substantially the same information required of an American issuer and to

13. The majority of deposits today are made by dealers, but on behalf of private persons who already hold shares in the foreign corporation. Interview with Assistant Secretary, Irving Trust Co., March 14, 1956. The dealers, of course, retain a strong interest in broadening the market for foreign securities, and consider the use of substitute certificates a "very material assistance" to that end. ADR REPORT 65. But the dealers no longer take an active part in the issuance or management of substitute certificates. $I d$. at 30 , 80-82. They "receive no fees . . . assume no duties . . . have no rights [and] . . . are not available to anyone." Id. at 82 . Inde'ed, today there is no separate agreement of deposit other than the agreement stating the terms of the deposit which is on the back of each substitute certificate. Ibid.; Guaranty Menio 7. The separate deposit agreement, see notes 6-7 supra, has thus been abandoned.

14. 48 Stat. 74 (1933), as amended, 15 U.S.C. $\$ 77 \mathrm{~b}(1)$ (1952).

15. 48 StAт. 883 (1934), as amended, 15 U.S.C. $\$ 78 \mathrm{c}(10)$ (1952).

16. In order to accommodate the particular characteristics of substitute certificates, the SEC established the registration statement Form C-3 to facilitate compliance with the 1933 Act. SEC, Securities Act of 1933, Release No. 1502, July 8, 1937. For sample form and instructions, see 1 CCH FED. SEC. L. REP. If 6701-22. Form 19 was made available to allow compliance with the separate registration required under the 1934 Act for all listed securities. SEC, Securities Exchange Act of 1934, Release No. 223, July 15, 1935. For sample form and instructions, see 2 CCH FED. SEC. L. REP. If 29401-08. For the annual reporting required by $\$ 13(\mathrm{a})$ of the 1.934 Act, the SEC at the same time released Form 19-K. See 2 CCH Fed. Sec. L. Rep. IIT 32101-04.

17. Section 2(4) of the 1933 Act provides:

"The term 'issuer' means . . . with respect to certificates of deposit . . . the person or persons performing the acts and assuming the duties of depositor or manager pursuant to the provisions of the trust or other agreement or instrument under which such securities are issued..."

48 StAT. 74 (1933), as amended, 15 U.S.C. $§ 77 \mathrm{~b}(4)$ (1952). While this definition was aimed primarily at voting trusts, the section was applied also to ADR's. See Loss, SEcuRItIEs Regulation 301-04, 304 n.15 (1951 ed. with 1955 Supp.) (hereinafter cited as Loss). Thus, when the depositor assumed managerial duties, as was generally the case, see note 7 supra, it was deemed the "issuer." Professor Loss concluded that the depositary was coissuer. Loss 304 n.15. But cf. note's 33-35 infra. 
sign the registration statement. ${ }^{18}$ However, the Securities Act exempted securities that were traded domestically before 1933 , or were traded by dealers not acting as underwriters. Since many of the securities represented by ADR's qualified for these exemptions, unlisted ADR's could be offered to the public without disclosure by the foreign company.19

With the passage of time, progressively fewer foreign shares could qualify for exemption from registration. Moreover, the number of exempt shares had always been a small proportion of the foreign shares available. Foreign companies were disinclined to make the revelations necessary for full registration, and the general lack of public interest in foreign investment during the thirties and forties discouraged ADR registrations. Since 1950, however, public interest in foreign securities has increased, and New York banks have attempted to expand their ADR services. ${ }^{20}$ In response to this renewed interest, the SEC has recently authorized the use of an even more abbreviated registration procedure. ${ }^{21}$ The new registration form, designated Form $S-12,{ }^{22}$ is available for use whenever (1) the holder may, under the terms of the ADR agreement,

18. Part II of both the Form C-3 (registration) and the Form 19 (listing) consists of the registration data that would be appropriate for the underlying foreign share. $1 \mathrm{CCH}$ FED. SEC. L. REP. \ 6714 (July \&, 1937) ; 2 id. \ 29407 (July 15, 1935).

In practice if not in theory, however, the C-3 form was not widely used; the SEC apparently required the depositary to supply a good deal of the information that would have been required of the foreign company in part II if it had had to register its shares directly, even though the foreign shares were exempt. See ADR REPORT 47-48. Failure to make the additional disclosure gave rise to a deficiency letter. $I d$. at 88 .

19. Section $3(a)$ (1) of the 1933 Act exempted from registration securities "disposed of by the issuer or bona fide offered to the public" prior to enactment of the legislation. 48 Star. 76 (1933), as amended, 15 U.S.C. $\$ 77 c(a)$ (1) (1952).

Section 4(1) of the 1933 Act exempted from registration securities transactions "by a dealer." 48 Stax. 77 (1933), as amended, 15 U.S.C. $\& 77 d(1)$ (1952). The investment houses dealing in the foreign shares qualified for exemption under this section unless they were distributing a new issue of the securities as an "underwriter," i.e., on behalf of the issuer or a controlling shareholder; or unless they themselves obtained a sufficient number of shares in the foreign company to constitute "control." A dealer with "control" was to be treated as both issuer and underwriter under the terms of $\$ 2(11)$ of the Act. 48 STAT. 75 (1933), as amended, 15 U.S.C. 77b(11) (1952). To date, however, ADR's have not becn introduced to such an extent by any single dealer that the $\S 4(1)$ exemption was lost.

20. Curb trading in ADR's issued by Guaranty Trust Co. of New York on the American Stock Exchange jumped from $\$ 1$ million in 1949 to $\$ 4.65$ million in 1954. ADR REPoRT 50. See also Business Week, June 4, 1955, p. 130; N.Y. Herald Tribune, Dec. 21, 1955, $\S 3$, p. 15, cols. 3-4; note 12 supra.

21. Form S-12, 1 CCH FED. SEC. I. REP. \ 7251, was released on November 17, 1955, as the result of hearings in Washington which followed a request for comments on a new registration form for ADR's. SEC, Securities Act of 1933, Release No. 3593, Nov. 17, 1955. See Business Week, Sept. 10, 1955, p. 69; id., Dec. 10, 1955, p. 50. The S-12 form applies, of course, only to ADR's not listed on a national securities exchange; if listed, separate registration would be required in compliance with Form 19. See note's 15-18 supra. The SEC does not contemplate relaxing requirements for listed ADR's. Letter from Manuel F. Cohen, Esq., Counsel, Division of Corporate Finance, Securities and Exchange Commission, to the Yale Law Journal, Mar. 5, 1956, on file in Yale Law Library.

22. 1 CCH FED. SEC. L. REP. If 7251 (Nov. 17, 1955). 
withdraw the underlying foreign share, and (2) the underlying share would not itself have to be registered. ${ }^{23}$

\section{Disclosure}

The new regulations do not provide for detailed disclosure. Only four items need be reported in the prospectus: (1) the identity of the depositary bank; (2) the fees and charges collected by it; (3) the terms of deposit, and (4) an undertaking by the depositary to make available to the SEC and to holders of the ADR's such reports as the foreign company may issue to it. ${ }^{24}$ If this information is on the face of the ADR, as it usually is, the certificate may be its own prospectus. ${ }^{25}$ The foreign company itself need not disclose anything beyond the minimal information required by foreign law..$^{26}$

These disclosure requirements seem inadequate. Although the foreign shares standing behind the ADR's may have been traded here as well as abroad for some time, the introduction of an ADR in this country is in many ways equivalent to a new domestic issue. The attractive simplicity of the ADR mechanism, and the ample publicity generally given to announcements of the availability of ADR's, serve to expand the market for these securities far beyond the wellinformed, specialized traders that buy actual foreign shares. But the nonspecialized American investor cannot be expected to be familiar with a company whose shares have never been registered in the United States. The detailed prospectus required for domestic securities is unknown abroad, and complete financial histories of foreign companies are seldom available. While it is true that adequate financial information about American companies is not always available, the difference in accounting standards and the non-availability of the foreign company as a party liable to the investor lend added weight to the arguments that have already been made for more adequate disclosure by unlisted domestic companies.

It is possible that in relaxing the requirements for registration, but not for listing, ${ }^{27}$ the SEC relied on the greater sophistication of the over-the-counter investor, and assumed that the unsophisticated investor trades primarily on the national exchanges. ${ }^{28}$ If this distinction has in fact been drawn by the SEC,

23. Form S-12, 1. CCH Fed. SEC. L. Rep. If 7252 (Nov. 17, 1955).

24. Id. $₫ 7253$.

25. Id. \ 7252. See note 13 supra.

26. The depositary undertakes only

"to make available for inspection by holders . . . any reports and communications received from the issuer of the underlying securities which are both (1) received by the registrant or depositary as holder of the deposited securities, and (2) made generally available to the holders of the underlying securities by the issuer."

Form S-12, 1 CCH Fed. Sec. L. REP. Iff 7253, 7254 (Nov. 17, 1955). As the foreign company has no obligation under our law to issue any reports, the depositary's undertaking is no guaranty of information.

27. See note 21 supra.

28. For contrast of the modes of operation of auction (stock exchange) and negotiated (over-the-counter) markets, see Loss 707-16; SEC, REPORT ON THE FEASIBIITY AND AD- 
it is in itself an admission of the dangers involved. In over-the-counter trading, the market for a given share often is made by a single professional trader. Unlike the situation in an open and well-reported auction market, the trader in a negotiated market can, to the detriment of the investor, control the trading of the ADR's he alone has introduced. ${ }^{29}$ Thus the simplified registration means a minimum of information and a maximum opportunity for manipulation.

\section{Liability}

Even assuming that sufficient disclosure is or will be required, the simplified form does not identify any party that assumes the traditional "issuer's" liability for the reliability of the data disclosed. ${ }^{30}$ The foreign company does not even sign the registration statement. The depositor, which formerly qualified and was liable as issuer because it undertook to "perform the acts and assume the duties" of managing the deposit, ${ }^{31}$ no longer does so under the modern scheme. Today, the functions formerly discharged by the depositor have in substance been assumed by the depositary bank. Rather than a separate contract of deposit between the depositary and a large depositor, there is now a series of separate deposits pursuant to an open-ended offer by the depositary to issue ADR's against deposits conforming to prescribed conditions. ${ }^{32}$ Yet by the SEC's express instructions, the depositary bank is not to be considered the issuer of the ADR's ;33 rather, the SEC has created a seemingly fictitious issuer. Its instructions read:

"[T] he entity created by the agreement for the issuance of the American Depositary Receipts (or any corporation or trust organized to act only as a conduit in connection with the deposit of the underlying securities pursuant to such an agreement) shall be deemed to be the issuer of the American Depositary Receipts for all purposes of this form and the Act."34

visability of the Complete Segregation of the Functions of Dealer and Broker 65-67 (1936) ; Twentieth Century Fund, The Security Markets 263-70 (1935). There are currently three foreign stocks traded in substitute certificates on the New York Stock Exchange, and fifty-six on the American Stock Exchange. There are, in contrast, several hundred foreign stocks traded over-the-counter for which the ADR mechanism could be utilized.

29. That the SEC is cognizant of this possibility is evident from the fact that it has restrained over-the-counter dealers from engaging in just such tactics. See, e.g., Norris and Hirshberg, Inc., 21 S.E.C. $\$ 65,874$ (1946).

30. "Issuer" is defined in $\$ 2(4)$ of the Securities Act of 1933; his liabilities for fraud, nondisclosure and misleadingly incomplete disclosure are defined in $\$ \S 11,12,17$. See 48 Stat. 74-75, \$2-\$5 (1933), as amended, 15 U.S.C. $\$ \$ 77 b(4), k, 1, q$ (1952).

31. Form S-12, 1 CCH FED. SEC. L. REP. If 7252 (Nov. 17, 1955), applies only when "no person or persons perform the acts and assume the duties of depositor or manager," the only capacity in which the depositor formerly was deemed to be the "issuer." See note 17 supra and accompanying text.

32. See notes 11-13 supra and accompanying text.

33. Form S-12, 1 CCH Fed. SEC. L. ReP. \ 7252 (Nov. 17, 1955). This is true even though the depositary signs the $\mathrm{S}-12$ on behalf of the issuer-registrant. Ibid.; see note 47 infra.

34. Form S-12, 1 CCH Fed. Sec. L. Rep. If 7252 (Nov. 17, 1955). 
Who this "entity" is, which agreement it was "created by," what duties it may be compelled to perform, and what assets it has or how they may be reached, have not been indicated.

The SEC's strangely obscure position as to the identity and liability of the issuer may stem from the banks' contention that, if the bank is considered to be the issuer of the ADR's, then ADR's are exempt from registration under section 3(a) (2) of the Securities Act. ${ }^{35}$ Section 3(a) (2) exempts from the Act securities "issued or guaranteed by any national bank, or any banking institution the business of which is . . . supervised by the State or Territorial banking commission or similar official. ..."36 At the SEC conference on ADR's which preceded the issuance of Form S-12, bank counsel strongly supported the view that the bank was the issuer, and that in consequence ADR's were exempt securities. ${ }^{37}$ At the suggestion of the conference chairman that the exemption was intended to cover only securities of the bank itself, not securities of an unrelated enterprise, ${ }^{38}$ bank counsel pointed to the "issued or guaranteed by" language of section 3(a) (2). If stock "guaranteed by" a bank could be exempt, it was argued, Congress clearly contemplated that securities other than bank securities could qualify for the exemption. ${ }^{39}$ Moreover, argued counsel, it was immaterial that state authorities did not in fact regulate the issuance of ADR's. In section 3(a) (2) Congress exempted securities issued by banks "the business of which . . . is supervised."40 And its express reference to regulation of the issuance of securities by the ICC, in granting a parallel exemption to carriers, indicated that it had consciously differentiated between supervision of a business in general and supervision of the issuance of particular securities. ${ }^{41}$

If the SEC accepted the argument that the bank exemption was applicable, there appeared to be no way of subjecting ADR's to regulation. The mechanics of issuance of ADR's are such that no party other than the bank could perform the issuer's functions, and no party could reasonably be deemed an "underwriter" or "dealer." 42 The Commission could therefore not deny that

35. ADR REPORT 87-88. In response to an inquiry in 1950 the SEC indicated that, in its view, if a bank were the "issuer" of an ADR, the $\S 3$ (a) (2) exemption would apply. Id. at 8. See letter from SEC to Winthrop, Stimson, Putnam \& Roberts, Aug. 24, 1950, p. 3, copy on file in Yale Law Library. When in 1955 the Irving Trust Co. attempted to implement the distribution of ADR's on the basis of this ruling, however, the SEC invited interested banks, brokers and dealers to attend a hearing at which the matter of the $\$ 3(\mathrm{a})$ (2) exemption could be reconsidered.

36. 48 Stat. 76 (1933), as amended, 15 U.S.C. \& 77c(a) (2) (1952).

37. ADR REPORT 24,$41 ; c f . i d$. at $54-58$.

38. Id. at 23 .

39. Id. at 24. See, however, text at notes 49-55 infra.

40. 48 STAT: 76 (1933), as amended, 15 U.S.C. $\$ 77 \mathrm{c}$ (a) (2) (1952). (Emphasis added.)

41. ADR REPORT 23-26, 41. But see notes 53-55 infra and accompanying text.

Section 20a of the Interstate Commerce Act places the issuance of securitics by railroads under the supervision of the ICC. 41 StAT. 494 (1920), as amended, 49 U.S.C. $\$ 20$ a (1952).

42. Cf. ADR REPORT 71; text at notes 11-13 supra. 
the bank was the "issuer," for it would then have no party liable for registration of ADR's, and would, indeed, lose all authority to regulate their issuance. ${ }^{43}$ But if the bank was the "issuer," ADR's became exempt securities, and neither the disclosure nor the liability provisions of the Act would be applicable. The ingenious theory which the Commission ultimately adopted appears to be a compromise fashioned to avoid both unsatisfactory alternatives.

In Form S-12, the SEC used the second "except" clause of section 2(4) of the Act for the dual purpose of imposing a duty of registration, and at the same time withdrawing liability for information disclosed in the registration statement. Section 2 states that the term "issuer" means "every person who issues or proposes to issue any security," and then narrows the definition in a series of "except" clauses. The second "except" clause provides that where the "issuer" is a "trust, committee, or other legal entity, the trustees or members thereof shall not be individually liable as issuers of any security issued by ... [such entity]." 44 It is this clause which, apparently, the SEC intended to invoke by its "entity" language in the instructions for Form S-12.45 But the second "except" clause was plainly intended to refer only to such arrangements as voting trusts and security-holders' protective committees in bankruptcy or reorganization. And its application to arrangements for deposit of foreign securities is almost bizarre, since, in the words of bank counsel, no "legal entity is created apart from the bank itself." 46 However, the SEC's formulation at once removed the bank from the definition of "issuer," and replaced it with a fictitious "entity" that was not within the bank exemption. Then, by virtue of its rule-making power, the SEC could allow the bank, as deposi-

43. Transactions by persons other than an issuer, underwriter or dealer are exempt under the 1933 Act. 48 Stat. 77 (1933), as amended, 15 U.S.C. $§ 77 d(1)$ (1952); Loss 123. In the modern context there is no possibility of holding the bank or any other party liable as dealer or underwriter. See ADR REPORT 41; text at notes 11-13 supra.

44. 48 STAT. 74 (1933), as amended, 15 U.S.C. $\$ 77 \mathrm{~b}(4)$ (1952).

The first "except" clause of $\$ 2(4)$ states that the person who "issues" the security is not the "issuer" where there is another party who performs the acts and assumes the duties of depositor or manager. Under the type of ADR that represents a separate deposit agreement, see notes 6-S supra and accompanying text, the depositor would, under 2(4), displace the bank as "issuer." This type of ADR is analogous to the certificates of deposit issued by banks on deposit of securities by such entities as bondholders' protective committees. But where there is no such agreement or depositor, as is more typical of the modern $A D R$, see notes 11-13 supra and accompanying text, the first "except" clause is inapplicable. ADR REPORT 71-74.

45. Manuel F. Cohen, Esq., Counsel, Division of Corporation Finance, SEC, suggested such a rationale in the course of the hearings. ADR REPORT SO-81.

46. ADR REPORT $\$ 1$.

It seems likely that, at the outset, the SEC visualized an "entity" in the nature of a joint venture between the banks and brokers dealing in foreign securities. Id. at 62-70, 82-83. There was at least historical justification for this view, in that the original mechanism for substitute certificates involved such an agreement between an investment bank and the depositary, $i d$. at 80 ; text at notes $5-10$ supra, and the SEC had oriented its regulations accordingly. However, the broker today plays no such role. See ADR REPORT 30; text at notes 11-13 supra. 
tary, to register in behalf of the "entity" that proposed to "issue" the securities."7 Moreover, since ADR's remained fully subject to the Act under this interpretation, the Commission could issue stop-orders if occasion arose.4s Meanwhile, since the SEC's theory made the bank liable only in its capacity as an "entity," i.e., not at a11, Form S-12 served the banks' purposes almost as well as a holding that the 3 (a) (2) exemption was applicable.

The flaw in the position of both the banks and the SEC is that ADR's are not exempt securities under section 3(a) (2). Bank securities were exempted from registration for two reasons: (1) federal and state regulatory agencies supervised banking activities, so that investors in bank securities were already to some extent protected; and (2) detailed disclosure to the public of information about the financial condition of banks might provoke runs. ${ }^{49}$ Obviously, neither reason supports extension of the bank exemption to ADR's, since federal and state banking authorities make no investigation whatever of the worth of securities underlying ADR's, ${ }^{50}$ and the information disclosed would in any event have nothing to do with the financial condition of banks. Moreover, the wording of the exemption statute does not support the banks' position. It is true that section 3(a) (2) exempts securities "guaranteed by" banks, but this language is entirely consistent with an intent to limit the exemption to the securities of banks themselves. For the worth of a bank's guarantee, like that of any other bank security and unlike that of an ADR, would depend primarily on the bank's own credit and financial condition. ${ }^{51}$ Accordingly, the disclosure that would be required on issuance of a guarantee would concern

47. In a typical Form S-12, the blank space labeled "Name of Issuer" is filled in with the words, "American Depositary Receipts for [foreign company]." The same words appear in the blank labeled "Registrant" at the conclusion of the form. The bank completes the form in the manner indicated and signs beneath "Registrant" as follows: "By [nams of bank] [signature and title of officer]." See sample registration form on file in Yale Law Library.

48. 48 Stat. 79 (1933), as amended, 15 U.S.C. $\$ 77 \mathrm{~h}$ (d) (1952); ADR RePoRT 46.

49. Because there are no legislative materials elaborating the purposes of the bank: exemption in $\S 3(\mathrm{a})(2)$, legislative intent must be inferred from the terms of the statute. The general understanding of the purposes of $\S 3(a)(2)$ is as stated. See the exchange between SEC Chairman Armstrong and bank counsel during the SEC hearings on regulation of ADR's. ADR REPORT 59-60; cf. Loss 354-55.

50. Banks concede that the banking authorities do not regulate the issuance of ADR's except to the extent of ascertaining whether in fact the underlying foreign securities have been deposited and are being safely held. ADR REPORT 61 .

51. Actually, it is generally believed to be ultra vires for a bank to guarantee the inyestment obligations of another enterprise. 4 Michie, Banks and Banking c. $7, \$ 4$ (perm. ed. 1931) ; 7 id. c. 15, $\$$ 163-64. National banks may deal in the obligations of other persons or entities only "without recourse." REv. STAT. $\$ 5136$ (1875), as amended, 12 U.S.C. \& 24 (1952). This rule applies to investment as well as to commercial paper. Awotin v. Atlas Exchange Nat'l Bank, 295 U.S. 209 (1935). Government securities are the only exception to this proscription. REv. STAT. $\$ 5136$ (1\$75), as amended, 12 U.S.C. $\$ 24$ (1952). Consequently, the only purpose of the "guaranteed by" language of the bank exemption clause seems to have been to insure that banks would not be compelled to register when and if they guaranteed government securities, themselves exempt from registration under $\$ 3(a)(2)$. 
the bank's own financial affairs. ${ }^{52}$ Furthermore, the clause's reference to securities issued by banks "the business of which . . . is supervised"53_used by the banks as an argument for exemption of ADR's ${ }^{54}$-actually reinforces the conclusion that Congress intended to include only bank securities within the scope of the exemption. ${ }^{\text {"5 }}$ Close federal and state supervision of the "business" of banks might well be deemed to obviate separate regulation of bank securities; it could scarcely obviate regulation of securities like ADR's, which are dependent on the "business" of an enterprise wholly unrelated to the bank. In short, there is no valid reason, in either the language or the policy of the Act, why the depositary bank should not be required to assume liability in law for the issuer's role it has assumed in fact.

\section{CONCLUSION}

Foreign companies that wish to make their shares more readily available on the American market through the medium of ADR's should be held to substantially the same disclosure requirements as domestic corporations. And the depositary bank, as the only responsible party available to the American investor, should be required to undertake the issuer's liability to insure that this disclosure is made and made accurately. It is true, as the banks have pointed out, that ADR's are now used primarily for established European enterprises. ${ }^{\text {50 }}$ But the SEC should recognize that the ADR is also available for the most speculative foreign uranium mine. ${ }^{57}$ And in any event, substitution of a

52. The guarantor of a security would, together with the obligor of the security guaranteed, file a standard Form S-1 registration setting out the required information concerning both guarantor and obligor. 1 CCH FED. SEC. L. Rep. IT 7121-29 (Oct. 25, 1955). The guarantor is considered to be the "issuer" of only the guarantee and not of the underlying security. See Lass 304-05, 362-63.

Guarantees are apparently most often used in connection with leases and consolidations. The acquiring company may find it more expedient to guarantee the debt or preferred dividends of the acquired company than to purchase them outright. 1 Dewing, THE Financhal Folicy of Corrorations 126 (5th ed. 1953).

53. 48 Stat. 76 (1933), as amended, 15 U.S.C. $\$ 77 \mathrm{c}($ a) (2) (1952). (Emphasis added.)

54. See note 40-41 supra and accompanying text.

55. In contrast to the bank exemption's reference to regulation of the business of banking, the exemption for carriers specifies securities the isstance of which is otherwise regulated. 48 Stat. 76 (1933), as amended, 15 U.S.C. $\$ 77 c(a)(6)$ (1952). The banks have argued from this contrasting language that the bank exemption was intended to embrace all securities issued by banks, whether the bank's own security or not, without regard to whether bank supervision actually affects the security in any material way. See text at notes $40-41$ supra.

But the argument may not be carried so far. It is doubtless true that Congress intended to exempt bank securities even where their issuance was not directly supervised by banking authorities. This exemption was deemed warranted, however, only by the policy against public disclosure of banks' affairs, and the protection already afforded to the investor by the constant surveillance of the financial affairs of banks. Neither of these reasons, nor any others that are apparent, support exemption of non-bank securities such as ADR's. Cf. note 44 supra (issuance by banks of certificates of deposit for securities).

56. Cf. list of shares for which ADR's are offered by the Guaranty Trust Co. of New York, on file in Yale Law Library.

57. This possibility was suggested by SEC Commissioner Orrick during the hearings 
bank's discretion for responsible disclosure as a protection for the investor is plainly inconsistent with the policy of the Securities Act. ${ }^{58}$

If there are any reasons for mitigating regulatory requirements applied to ADR's, they must be drawn from policies outside the purview of securities regulation. The banks have pointed particularly to the explicit policy of the United States to encourage foreign investment. ${ }^{59}$ ADR's plainly facilitate foreign investment, and imposition of disclosure and liability requirements would unquestionably discourage their use. Foreign companies might balk at making full disclosure of financial information. And the banks have warned that the fees collected for issuance of ADR's would not cover the expense of full registration and the dangers involved in assumption of liability. ${ }^{60}$ However, if these burdens were imposed they could readily be shifted by the bank to the foreign company. And the stake of the United States in facilitating investment in foreign concerns that are unwilling to make responsible disclosure of their financial condition is, after all, not necessarily decisive. If the American investor were restricted to properly registered companies, the effect on United States economic policy would be considerably less than disastrous. ${ }^{61}$

Even if the SEC might reasonably elect not to apply full disclosure and liability requirements to ADR's, it need not leave the investor completely unprotected and unwarned. Several intermediate courses might readily be taken: the Commission might, for example, impose modified disclosure requirements, less stringent than those applicable to American companies. ${ }^{62}$ The form adopted might list the items of information usually included in a registration which have not been disclosed by the foreign company concerned. Less satisfactory, but still an improvement, would be a requirement that purchasers of ADR's be warned in advertisements and on the face of the certificates that no disclosure has been required, and that, short of fraud, no party in the United States is legally responsible for the accuracy of information that may be obtained. A minimum corrective effort that seems required is for the SEC to abandon its ostensible reliance on a nonexistent "entity," and to inform the public in comprehensible terms of its attitude toward the regulation of ADR's. ${ }^{63}$

on Form S-12. ADR REPorr 83. Counsel for Irving Trust Co. conceded that it was "technically" possible. Ibid.

58. Loss 82-83; Douglas \& Bates, The Federal Securities Act of 1933, 43 YALE L.J. 171,214 (1933).

59. ADR REPORT 100-02.

60. See ADR REPORT 46.

61. Actually, foreign investment by American companies has so far outdistanced portfolio investment, see note 1 supra, that the net flow of capital abroad would be little affected by limiting the availability of portfolio investments. For an example of the effect of direct investment by American industry, see Business Week, March 31, 1956, pp. 132-42.

62. The SEC already imposes less stringent requirements on foreign companies, exempting them, for example, from the proxy and insider trading provisions of the Securities Exchange Act of 1934. Loss 528, 589.

63. On the desirability in securities regulation of "clear expression of principle" and "unambiguous treatment of detail," see Douglas \& Bates, Some Effects of the Securitics Act Upon Investinent Banking, 1. U. CHI. L. REv. 283, 306 (1933). 